\author{
Sidey Myoo \\ Department of Aesthetics, Institute of Philosophy \\ Jagiellonian University \\ michal.ostrowicki@uj.edu.pl
}

\title{
INTERACTIVE ART IN THE CULTURE OF PARTICIPATION
}

\begin{abstract}
This paper highlights the concept of participation from two perspectives, that is cultural engagement, which shall serve as an initial and conceptual background, and the proper analysis drawing on the phenomenon of participation in the interactive art which has emerged from the New Media Art. The former aspect needs attention because of the still increasing importance of interactive technology, predominantly for the purposes of the Web users and their Web mediated participation practices. However, the Author would like to ponder over the importance of participation in the era of electronic media which is seen as a meaningful feature of the mechanisms of modern culture.

The latter aspect of the analysis refers to the issue of reception of interactive art. This paper aims to reflect on how this area of communication between the artist and the viewer is essentially different in contrast with the so called proscenic art, because it involves a new and very interesting phenomenon of interference of the recipient in the work of art and, consequently, allowing them to become a part of it.

Some modern artworks shall serve as examples for my studies, e.g. an interactive 3D installation and Post-Internet Art works.
\end{abstract}

Keywords: interactive art, participation, electronic media, cyberculture New Media Art.

\section{Interactive and Proscenic Arts}

The issue of recipient's participation in the work of art to be discussed hereunder refers to a broader context of the culture of participation that emerged at least three decades ago. ${ }^{1}$ Specifically, I mean dramatic changes in modern

1 H. Jenkins, Convergence Culture. Where Old and New Media Collide, New York and London, New York University Press, 2006, p. 5. 
world emerging from the still increasing importance of the mediation practices, meaning the use of increasingly more advanced equipment and the need to access the Web. ${ }^{2}$ This implies that many people have transferred their life activities to the Internet and their intentionality is forwarded there either, which means that many of their relationships and life in the physical (real) world have become reduced to a significant extent. ${ }^{3}$ The phenomenon of interactivity is addressed here as a property of cyberculture that is followed by every human being's need to participate, in other words the click culture. This broader meaning of participation, ${ }^{4}$ related to the development of technology, may also be seen as an important factor for the growth of interactive art and changes of ways it is interpreted and received, that is from the manner it has been understood as a proscenic artwork to the real and physical response to the work of art: “...participation in interactive works using ubiquitous computing and mixed reality. It supports and analyses work of artists and creative practitioners incorporating or reflecting on participatory processes to support new roles and forms of engagement for art participants." 5

Here, the concept of participation refers to a holistic and qualitative understanding of people, their interests, quests and search that are discernible in the process of their interactive aesthetic experience as well as emotional and intellectual commitment. ${ }^{6}$ The notion of interactivity here refers to quantity

2 S. Turkle, Always-On/Always-On-You: The Tethered Self, in: Handbook of Mobile Communication Studies, ed. James E. Katz, MIT Press, Cambridge MA, London 2008, pp. 121-137.

3 D. Bell, Introduction to Cyberculture, Tylor and Francis Group, Routledge, London and New York 2001, p. 62.

4 Ulises Ali Mejias shows an important aspect of participation, which is associated with the employment of electronic media for the purposes of manipulation of even large user communities. This is possible due to media information (on the Internet and TV, mainly), which affects user's decisions in physical environment (reality): "Even as we continue to participate in digital networks, we should keep in mind that participation is full of contradictions, and those contradictions define our contemporary existence. In an economy where profit is derived by capitalizing on the participation of users (through advertising, data mining, etc.), and where a handful of buyers acquire and distribute the bulk of user-generated products, great power can be exercised by corporations in setting the conditions under which social exchange can take place". (U. A. Mejias, Off the Network. Disrupting the Digital World, University of Minnesota Press, Minneapolis, London 2013).

5 G. Jacucci, M. Wagner, I. Wagner, E. Giaccardi, M. Annunziato, J. Hansen, K. Jo, S. Ossevoort, A. Perini, N. Roussel, S. Schuricht, ParticipArt: Exploring Participation in Interactive Art Installations, "Arts, Media, \& Humanities Proceedings", IEEE International Symposium on Mixed and Augmented Reality, Korea, Seoul, 2010, p. 3: https://www.cs.helsinki.fi/u/jacucci/ participart.pdf (all links have been checked in 5.09.2018).

6 One of the most significant project where the mentioned properties are visible is Portrait One by L. Courchesne'a, an installation using video art approaches. The artist used a traditional CRT and a dialogue menu. The audience is supposed to engage in a conversation, 
arising with a phenomenon of development of technology and the potential for participation. And, participation is defined here as man's attitude to any activity, interactivity means their openness for change coming with technology. Modern artwork allows the recipient to interfere and discover more and more new structures and interpret the work of art.

My study of the phenomenon of participation draws on fundamental difference between interactive and proscenic art. The proscenic artwork invoke a bulk of fine art created throughout history, including films or stage plays (experimental and unique attempts to introduce some forms of interactivity to stage plays or films have been left out from these reflections on purpose). In this article, proscenic $\operatorname{art}^{7}$ means the artwork where the aesthetic experience does not interfere with its invariable form, and the participation of the recipient is only intentional, for example a novel ${ }^{8}$ that needs only the involvement of reader's imagination of the scenery that denotes the reader's specific participation. As advocated, the proscenic and interactive experiences of art are different and they use different strategies of involvement: the first case requires imagination, contemplation and experience that mean the inherent processes; the latter case additionally requires an active approach of the recipient, who could physically interfere with the form and content of the artwork.

However, it seems necessary to note that defining the interactivity in art, I abandon many views on the question unaddressed, that means in particular those which stress the relation between the interactivity and participation.

deemed as an aesthetic experiment, with a woman bearing a fictitious name Maria (Paule Ducharme). It is interesting that the employment of technology was not hidden and it was clear that the audience chats with a recorded image of a woman by pressing the buttons of the menu of only a few questions which appear in the window. However, the conversation may be so involving and emotionally meaningful that it could last for several minutes when the participant may even disclose their sensitive information: http://www.fondation-langlois. org/html/f/page.php?NumPage=157, https://vimeo.com/5827424

7 A good example of proscenic art inspired by New Media Art could be the controversial project of Post-Internet Art, namely 5 milion dolars 1 TB (2011) by Manuel Palou. In the artwork's gallery there was a 1 TB disk with content obtained from the Internet, albeit without the required legal permissions, worth 5 million dollars, including non-free software and books (mainly science-fiction). This project openly violates copyright and supports the idea of free and open source code access software. The artist suggests like many Web users that due to the nature of the Internet technology its products should be free and easily accessible for all and arguing that Internet is a common space where it is essential to share and making access, but not making any form of barriers. This project challenges above mentioned views, which is specifically apparent due to its exposure in the art gallery and thus making the artist potentially liable for any legal failures: https://rhizome.org/editorial/2011/aug/16/5-milliondollars-1-terabyte-2011/

8 M. -L. Ryan, Narrative as Virtual Reality: Immersion and Interactivity in Literature and Electronic Media, The John Hopkins University Press, Baltimore and London 2001. 
Those claims acknowledge the interactivity in proscenic art (I am not going to discuss them in more detail here) by its potential to engage emotions, evoke multiple meanings and symbolisms, narrative, and intellectual and emotional "depths" for recipients' intentionality. ${ }^{9}$ Similar views were examined in Participation. Documents of Contemporary Art ${ }^{10}$, where the history of participation in the work of art has been revealed at least since the beginning of 20th c., and where the recipient's participation is linked with infinity of interpretations, semantic openness and a variety of dimensions of a work of art with allusions to classical texts such as Poetics of Open Work by Umberto Eco, The Death of the Author by Roland Barthes, or The Negation of the Autonomy of Art by the Avant-garde by Peter Bürger. These authors used terms like open work, autonomous or innovative work, where the recipient may experience its dialogism and not its interactivity, which we may encounter in electronic media. Such views demonstrate the need to move away from strong objectivity of artworks, but we need to note that this meaning is rather metaphorical and not so verbatim as in the case of interactive art using new media.

My point is to show that the above concepts do not fit within the interpretation of modern interactive artwork and need further development. Specifically, I mean the term where participation is understood as a dialogue with the artwork associated with responsive art work environment, and where a perceiver "...became energetically involved in the creation of abstract fields of interacting forms and colors rather than mimetic art, of images, objects, environments, and events perceived from multiple perspectives rather than from a single-point -of-view perspective, and of art inviting active participation rather than passive observation." 11

That denotes modern art that adopts interactive technology and allows the recipient to "get in" the artwork, and therefore become a part of it or a cocreator. ${ }^{12}$ This form of participation which is linked with interference with the

9 It is important to note that this different form of participation than the proscenic participation allows the viewer to co-create their artwork on the basis of previously prepared design: "From a participatory design perspective, an interesting aspect of this inheritance is the focus on media and technologies supporting creative and open-ended activities in relation to which the artist is more of a meta-designer than a conventional author" (G. Jacucci et al., ParticipArt: Exploring..., p. 4: https://www.cs.helsinki.fi/u/jacucci/participart.pdf ).

10 C. Bishop, Participation. Documents of Contemporary Art, Whitechapel and The MIT Press, Cambridge MA, London 2006.

11 M. Alexenberg, The Future of Art in a Digital Age: From Hellenistic to Hebraic Consciousness, Intellect Books, United Kingdom, The University of Chicago Press 2011, p. 82.

12 B. Costello, L. Muller, S. Amitani, E. Edmonds, Understanding the Experience of Interactive Art: Iamascope in Beta_space, in: Proceedings of The Second Australasian Conference on Interactive Entertainment, ed. Y. Pisan, University of Technology, Creativity \& Cognition Studios Press, Sydney 2005, pp. 49-56: https://opus.lib.uts.edu.au/bitstream/10453/11518/1/20060 14049.pdf 
artwork may often bring irrevocable and/or long-lasting consequences as it may be the case of some Net Art works.

Interactive participation makes it possible to see new facets of a given artwork, because its changing structures may inspire the recipient to discover new dimensions and accept its rules of communication. Furthermore, such type of interactive art could lead the viewer to interfere with the artwork: "The art most recently known as 'new media' changes our understanding of the behaviors of contemporary art precisely because of its participation in the creation of a cultural understanding of computational interactivity and networked participation. In other words, art is different after new media because of new media - not because new media is 'next', but because its behaviors are the behaviors of our technological Times." 13

Similarly, Nicolas Bourriaud in his Relational Aesthetics locates interactivity in a broader perspective by including in it multimedia related strategies. Interactive art is a breakthrough artistic idea which increasingly spreads its impact on artists from '90s of the last century when it altered the paradigm of artwork related behaviors, and specifically its types and reception: "As for the space of reflection opened up by Marcel Duchamp's art coefficient, attempting to create precise boundaries for the receiver's field of activity in the artwork, this is nowadays being resolved in a culture of interactivity which posits the transitivity of the cultural object as a fait accompli. As such, these factors merely ratify a development that goes way beyond the mere realm of art. The share of interactivity grows in volume within the set of communication vehicles. On the other hand, the emergence of new technologies, like the Internet and multimedia systems, points to a collective desire to create new areas of conviviality and introduce new types of transaction with regard to the cultural object."14

Bourriaud claims that participation is composed of the structure of two relations and three components of art, aesthetic ideas and real world where the aesthetics plays the role of the coupled mediator. He determines that the first relation is the association between art and aesthetic views, and the next one is linked to artist's aesthetics and reality. ${ }^{15}$ The latter is important, because it introduces next aspects of social and cultural investigations where the role of aesthetics which is seen as art criticism or artwork exhibitions is to involve political views, shared values and to confront and corroborate social art practices.

13 S. Dietz, Foreword, in: Beryl Graham, Sarah Cook, Rethinking Curating. Art after New Media, Cambridge MA, MIT Press, London 2010, p. xiv.

14 N. Bourriaud, Relational Aesthetics, Collection Documents sur art, translated by Simon Pleasance \& Fronza Woods with the participation of Mathieu Copeland, Les Presses du réel, Dijon 2002, p. 11 .

15 N. Bourriaud, Relational..., p. 19. 
Bourriaud believes that art is a negotiated medium that uses aesthetics to establish theoretical grounds for artwork's interpretation. Therefore, the role of aesthetics is to interpret art through related aesthetic judgments and analyses, and, furthermore, to describe it in terms of e.g. intervention, critical, protest, irony of affirmation forms of art. Then, the interactive participation in art practices denotes the process where the viewer is open to comments on and experience of the reality and participation. And accordingly, they are encouraged to express their views in real world owing to their art experience, and often take political and/or social actions. Bourriaud argues that art behaviors are potentially able to establish meaningful and responsible human relationships, and the role of aesthetics is to provide a vehicle/container with a number of references to the reality which affect further connotations contributing to establishing broader net of referrals. ${ }^{16}$

Domenico Quaranta, aesthetician and art curator, while making comments on Bourriaud's ideas, says in his Beyond New Media, that processes discussed above have been dominated by technology, and therefore the art negotiated behaviors are possible only owing to the mediation of technology, and precisely, Web technology. ${ }^{17}$ The Web is a place where such a system of behaviors emerges where the concept of user participation is associated with the process of interminable, negotiated and interactive behaviors/practices affecting the art production that could only exist in the context of clickable generation of cyberculture. One could discern there the phenomenon of materialization of philosophical views on the constraints of the transformation of man's forms of being, which result from the development of interactive technology. This is an ongoing and uninterrupted process that could not be blocked, and, what is also evident, its mechanisms have been adapted by artists, who, consequently, more and more often use electronic media and its presentation opportunities. I mean this form of art that is consciously and progressively contextualized within the spirit of time, and its current social, political, aesthetic ideas. Apparently, negotiated aesthetic strategies become only meaningful if they affect and are framed within currently debated issues that may be seen through aesthetic terms. "In other words, if used cleverly, technological media may offer precisely the tools needed to reflect on the profound ways in which that very technology is deeply embedded in modes of knowledge production, perception, and interaction, and is thus inextricable from corresponding epistemological and ontological transformations. I believe that such a meta-critical approach is operating in the best NMA [New Media Art] (and the best digital humanities scholarship.) Rather

16 N. Bourriaud, The Radicant, Lukas \& Steinberg, New York 2009.

17 D. Quaranta, Beyond New Media, Link Editions, Brescia 2013, pp. 189, 244. 
than shunning technological media, this method may offer artists the most advantageous opportunities to comment on and participate in the social transformations taking place in digital culture, in order to, as Bourriaud implores, inhabit the world in a better way." 18

This type of negotiated and active forms of participation relies on seamless transformations of the society where aesthetics may be apprehended as the language, and interactive technology artists' tools and techniques, and the art is progressive and related to current social issues. With media users who may become a part of the participation culture, interactive art has a chance to transfer universally understood and meaningful message for them which otherwise could not be attained. By using common social and aesthetic contexts and symbolic language of the Internet, or cultural interface as Lev Manovich says, artists could render various ideas and attitudes which may be broadly understood despite various characteristics of web users, their social background and shared ideologies. ${ }^{19}$

\section{Interactive Participation: Intensity of the Aesthetic Experience}

In order to clearly present my ideas on interactive art participation I wish to highlight three examples of New Media Art where it plays part in uninterrupted and subversive content to be revealed in artworks. ${ }^{20}$ It could be desirable to refer to: 1) an interactive work which has exemplary features of Post-Internet Art, accessible both on the Internet, and involving commitment in the physical world; 2) an Internet installation using 3D graphics and AI; 3) Mixed Reality installation, 4) a proscenic installation using $3 \mathrm{D}$ graphics. The last two installations mentioned before use Head-Mounted Display technology, that is, in other words, Google VR.

My point is to demonstrate that interactive participation allows recipients to experience artwork very powerfully, because they are not passive viewers but active participants in the changing chain of events. Though my illustrations mainly come from recent years, however, it is worth noting that similar works have been appearing since the turn of '1960s and '1970s. Specifically, I mean installations by M. Krueger Metaplay (1970), some artworks by Christa Sommerer and Laurent Mignonneau, including Interactive Plant Growing (1992),

18 D. Quaranta, Beyond..., p. 230.

19 L. Manovich, Visual Semiotics, Media Theory, and Cultural Analytics (Introduction for Lev Manovich, Теории софт-культуры) [Theories of Software Cultures] (Нижний Новгород: Краснаяласточка, 2017):http://manovich.net/content/04-projects/103-visual-semiotics/manovich_visual_semiotics.pdf

20 A. Vierkant, The Image Object Post-Internet, available on the Internet in 2010: http://jstchillin.org/artie/pdf/The_Image_Object_Post-Internet_a4.pdf 
Ken Goldberg Telegarden (1995), Eduardo Kac Uiarpuru (1999) and the series Mirror by D. Rozin.

The first performance on my mind to reflect on due to its involvement of many subjects and identities is Sazae Bot (2010) by Machiko Hasegawa and Hitoyo Nakano, often classified in terms of Post-Internet Art. On the one hand, it refers to broader phenomenon of mass interactive participation on the Internet, clearly it shows that nowadays it is impossible to abandon it, and the question of convertible and/or anonymous identities. It seems that from the broader perspective of culture of participation the questions of identities has a specific phenomenon that reveals possible creation of alternative identities on the Internet versus physical (real) world identities. This happens when a person starts to present their new Internet image, and then to express his/her views and needs without any constrains. Such a fictitious person could serve as a tool for expression of personality, either totally separate from the physical identity, or only showing some limited references. Internet users need long time experience and participation in Web activities in order to develop their new harmonious Web personalities and effectively operate both on the Internet and in physical world. Such a radical transformation of personalities is rare, and one may doubt if it is actually possible at all, because the environment of the physical world does not allow for establishing a comparable level of anonymity as on the Web, which seems a precondition for overcoming restrictions and limitations encountered in the physical world and then showing alternative nature, communication strategies, and often enforcing the Web users to face dilemmas determined by cultural communication filters.

Interactive forms of participation could become a real opportunity to start a new, second identity which could be effectively hidden before other Web users. As mentioned above, Sazae Bot was started on the Twitter social media environment, where its users could freely operate it. Essentially, the bot does not involve a singular user, but it affects fluid identities of many persons interacting with it. When engaged in a conversation with Sazae the users assume that it has a multi-faceted identity, and in a given moment only one "person" of this multi-component entity is revealed in the interaction. The users are not even able to verify whether they chat either to a human or to an AI bot acting as an independent thing. Ultimately, the aforementioned ambiguities may seem irrelevant, as remote communication does not require physicality and/or biologism. What is crucial is a rewarding communication in the chat, which, owing to participation of a plurality of identities in AI, may become more pleasing than a conversation with a human. The Sazae bot does not have a humanrelated identity, as it is composed of a set of many linguistic structures and determined by a number of characters. In turn, Sazae community members have decided to depersonalize their identities. Such a need is so important that 
the Sazae bot community members, if they meet in the physical world, they put on paper bags on their heads in order not to disclose their identity existing in the physical world nor betray their shared community values giving priority to Sazae and its multi-faceted identity:

"The concept of SAZAE bot is 'Anonism', which indicates anonymous activities. Anonism demonstrates the idea of devoting one's consciousness to anonymous activities throughout their daily lives. The advent of the Internet has given us humans a deeper awareness of the concept of anonymity, and has made it accessible to our lives. SAZAE bot aims to make humans conscious of our need to free ourselves from our status and titles, and our need to express actions with deeper consciousness - especially when we are anonymous, which is when our soul is closest to the naked state. [...] ...it aims to spread and take root in society as a positive and standard idea in order to help humans adapt to a new environment that will be formed by the technological evolution."21

Basically, the Sazae bot is a project on Twitter, where interactive participation with the users takes place. However, any references to the physical world, i.e. meetings of the Sazae community members have become a well established custom adding to their Internet anonymity and depersonalization.

A similar phenomenon of emerging Internet identity, but with the AI as a key component, is the project Training 2038 (2017) by the group Kitchen Budapest. Its theme highlights the process of training of an intelligent bot in 3D environment. As aforementioned, this work touches the question of multiidentity participation, but emerging in a AI which has been developed through interaction with the human.

The projects ideas target profound questions of modern world, whether or not the human could be subject to endless processes of algorythmization? or some human specific features (friendship, kindness, love?) resist them? Some artists assert that human creativity and/or emotionality is the barrier against algorithmization. In the case of Training 2038 the artists address the realm of the algorithmization of the morals: "The project also challenges the concept of anthropomorphizing non-human agents and calls attention to the potential dangers it will have if we fail it. In the end, it is not only the question whether bots are able to acquire moral conscience as we know it, but do we ourselves possess a coherent view of it to pass it over or not. Training 2038 serves as a cautionary tale also, seen from this perspective?"22

21 Sazae Bot was awarded in the category of Digital Communities on Ars Electronica 2016: http://prix2016.aec.at/prixwinner/21553/

22 Kitchen Budapest website, where info on Training 2038 is available: http://kitchenbudapest. $\mathrm{hu} / \mathrm{en} /$ project/training-2038 
The AI scholars and engineers are more and more deeply preoccupied with similar themes, because Artificial Intelligence affects more and more technologically advanced areas of social life like: autonomous cars, medical diagnoses, school education, nursing care therapeutic processes including recognition and response to emotions. In Training 2038 the function of interactive participation is to teach AI and allow it to understand how to deal with moral dilemmas. The AI faces here moral concerns about how to learn ethical conduct while being unable to handle semantic ambiguities.

Philosophical consequences of the aforesaid experiment refer to the renewed questions about the objective/subjective nature of good and evil, and only then the possibility to help us make moral decisions. In the case of AI, we could observe the process of transcending moral values, meaning that AI collects new knowledge about the morality from the human users and, possibly, renders it as objective on its own terms. Thus, its database and experience constantly expand so that ultimately it could accumulate expertise and operate as specialized software. If it could turn out that it is possible to algorithmize morality at all and the AI operations could be acceptable (at least in most cases) in line with our ethic values, it could lead us to the conclusion that we can reasonably believe in the objective nature of goodness and evil. Though this type of objectification does not fully correspond to Platonic terms, this idea could be supported by the experiences and views of many people that have been collected in the AI, which is, obviously, a more reliable basis for argument than views of a person or a group sharing similar values.

The understanding of the nature of moral values by specific individuals may seem partial/biased and limited, and, clearly, not a good foundation for their in-depth cognizance. Human value assertions as determined by subjectivity are challenged by artificial system which has an extensive database on morals and ability to use it. Joint interactive participation, reflections on morals, and establishing a joint domain with clear reference to morality serve the purpose to build up objective knowledge about moral values.

Both projects discussed above employ multi-entity interactive participation with the first one aiming to depersonalize the Sazae community members, and the second one stressing the importance of the bot's subjectivity and then discovering moral principles guiding its behavior. Any user is free to contribute to the content of above projects, and, in that way, add to their success (Sazae bot is accessible on Twitter, and Training 2038 is operated as an installation) like the interactive technology without which such ambitious artistic ventures and unlimited process of reception could be impossible.

Other examples of interactive artworks that employ VR technology (Google VR) and convey unconventional ideas may include Neighbor by Naotaki Fujii (2016) and Out of Exile by Nonny de la Peña (2017). The first one takes advan- 
tage of mixed reality by offering the recipient some images which correspond to current situations taking place around them in the physical world, and, additionally, computer-generated simulations intertwining with the images. The viewer needs to put on the aforesaid interface (Google VR) and may participate in a 6-minute performance in physical space around them, while watching simultaneously virtual and imitative images on display. This technique allows to interestingly juxtapose a clear and natural elements with enigmatic, but also existing in a natural and real ways. The mixed reality technology allows the user to interactively participate in a situation which is not clear and self-evident, and come to existential conclusions that the everyday reality is much more complex than it may seem and, e.g. become aware of unpredicted consequences of some life events or their relationships with other persons. The immersion in the interactive and mixed reality is supposed to incline the user to reflect on and/or become aware of the nature of common events and patterns existing in everyday life which could comprise unclear, but determining factors to be revealed only in the situation when an unpredicted, unprecedented and rarely occurring stimulus emerges and in this way changes familiar existence into an alien and displaced world: "The immersive art performance Neighbor visualizes the subjective process and will predict the future pattern of social bonding. Two participants wearing HMD and headphones stand facing each other at the center of the stage. Over a period of six minutes they see live images or a recorded past, or mixture of the two, which blurs the self/other boundary. They are advised to use their hands in order to interact with the other participant and create a new relationship. The two performers interact with the participants in real and virtual space. The participants' views are displayed on the screen. As witnesses, audiences can observe the participants' subjective experience and feelings through the stage and screen." 23

Such an unusual perception is only possible due to VR and immersion in the mixed reality. We owe the possibility to observe so many complicated dimensions interacting in the reality only to VR technology which allows us to perceive its physicality, intentions and gestures of moving persons, etc., but it is the interactivity which allows the audience to participate in the situations modeled in artistically unpredicted ways, and to face and react to unpredicted stimuli. The participant is not expected to formulate any aphoristic statements about the essence of the reality, but they have a chance to "try" the flavor of this unpredicted reality owing to the employed technology and artistic techniques.

It is worth discussing the proscenic project Out of Exile (2017) by Nonny de la Peña, where a VR display plays similar role as in the above-mentioned

23 Naotaka Fuji's website where info on Neighbor is available: http://neighbor.grinder-man. com/ 
work. It is not interactive venture in the sense I have employed so far, but its immersive Google VR technology allows the viewer to experience the sensation of being in the situation created by $3 \mathrm{D}$ graphics. The audience may only change the perspective that is the sole feature of interactivity encountered in this project. The employed technology made it possible to create a space for the study of the critical situation where the audience is expected to take a stance on morally challenging perspective, which could lead to even change their former worldview.

The immersive technology totally detach the viewer from the outer physical world which makes them concentrate on information flowing from virtual world simulating the physical one. This created world is to serve as a "laboratory" to test the experience of emotions in the convincing alternative conditions like in the situation encountered in the physical world. The audience is literally able to enter the created artistic situation, in this case reflecting obscure and painful situation where a member of a family is excluded and marginalized due to their sexual orientation. The participation in this scene allows the audience to experience the mental and physical violence exercised on the other person who has been repelled from the family because of their gender identity. Though the participant's role is only to observe, they experience the scene as if it happened in their presence which may lead to a form of catharsis, making assessments and understanding of the situation: "...the scene turns startlingly dramatic and violent. Using real audio combined with walk around virtual reality that puts the audience inside the story, Out of Exile is a powerful parable of the kind of hostility faced by so many in the LGBTQ community." 24

The viewer's presence inside this installation grants them an opportunity to feel the tragic dimension of the suffering of such persons, which would not be possible without the 3D technology. Though this participation is not interactive, it does not involve imagination of the viewer but their authentic commitment in the artistically created scene.

The interactive participation could lead to the viewer's identification with the heroes, which may cause them to cross the boundaries of the stage, a museum or glass. The move from proscenic to interactive arts, seemingly, affects the level of audience engagement and, to certain degree, their responsibilities for the aesthetic experience, which in turn change outer appearances and imagination in the process of content emanation/absorption determined by the artwork and its recipient.

24 Out of Exile was awarded in the category of Computer Animation / Film / VFX on Ars Electronica 2017: http://prix2017.aec.at/prixwinner/24719/ 


\section{BIBLIOGRAPHY}

Alexenberg Mel (2011) The Future of Art in a Digital Age: From Hellenistic to Hebraic Consciousness, United Kingdom: Intellect Books, The University of Chicago Press.

Bell David (2001) Introduction to cyberculture, London and New York: Tylor and Francis Group, Routledge.

Bishop Claire (2006) Participation. Documents of Contemporary Art, Cambridge MA, London: Whitechapel and The MIT Press.

Bourriaud Nicolas (2002) Relational Aesthetics, Dijon, Collection Documents sur art, Translated by Simon Pleasance \& Fronza Woods with the participation of Mathieu Copeland: Les Presses du réel.

Bourriaud Nicolas (2009) The Radicant, New York: Lukas \& Steinberg.

Costello Brigid, Muller Lizzie, Amitani Shigeki, Edmonds Ernest (2005) Understanding the Experience of Interactive Art: Iamascope in Beta_space, [in:] Y. Pisan (ed.) Proceedings of The Second Australasian Conference on Interactive Entertainment. Sydney: University of Technology, Creativity \& Cognition Studios Press, pp. 49-56: https://opus.lib.uts.edu.au/bitstream/10453/11518/1/2006 014049.pdf

Dietz Steve (2010) Foreword, [in:] B. Graham, S. Cook, Rethinking Curating. Art after New Media, Cambridge MA, London: MIT Press.

Jacucci Giulio, Wagner Mira, Wagner Ina, Giaccardi Elisa, Annunziato Mauro, Hansen Jonas, Jo Kazuhiro, Ossevoort Stijn, Perini Alessandro, Roussel Natacha, Schuricht Susanne, ParticipArt: Exploring Participation in Interactive Art Installations, "Arts, Media, \& Humanities Proceedings", IEEE International Symposium on Mixed and Augmented Reality, Korea, Seoul, 2010: https:// www.cs.helsinki.fi/u/jacucci/participart.pdf

Jenkins Henry (2006) Convergence Culture. Where Old and New Media Collide, New York and London: New York University Press.

Manovich Lev (2017) Visual Semiotics, Media Theory, and Cultural Analytics (Introduction for Lev Manovich, Теории софт-культуры) [Theories of Software Cultures], Нижний Новгород: Красная ласточка: http://manovich.net/content/04-projects/103-visual-semiotics/manovich_visual_semiotics.pdf

Mejias Ulises Ali (2013) Off the Network. Disrupting the Digital World, Minneapolis, London: University of Minnesota Press.

Ryan Marie-Laure (2001) Narrative as Virtual Reality: Immersion and Interactivity in Literature and Electronic Media, Baltimore and London: The John Hopkins University Press.

Turkle Sherry (2008) Always-On/Always-On-You: The Tethered Self, [in:] James E. Katz (ed.), Handbook of Mobile Communication Studies, Cambridge MA, London: MIT Press, pp. 121-137.

Quaranta Domenico (2013) Beyond New Media, Brescia: Link Editions.

Vierkant Artie (2010) The Image Object Post-Internet: http://jstchillin.org/artie/pdf/The_Image_Object_Post-Internet_a4.pdf 


\section{SZTUKA INTERAKTYWNA W KULTURZE PARTYCYPACJI (streszczenie)}

Celem artykułu jest zaprezentowanie partycypacji na dwóch płaszczyznach: kulturowej, co zostało omówiono w zarysie, będąc tłem dla zasadniczej analizy, tj. partycypacji w sztuce interaktywnej, powstającej na gruncie Sztuki Nowych Mediów. Ta pierwsza płaszczyzna wynika ze wzrostu znaczenia interaktywnych technologii, w tym głównie Sieci i zwiększającego się zapośredniczania użytkowników do Sieci. Ograniczono się tutaj do pokazania znaczenia partycypacji w czasach mediów elektronicznych, jako ogólnego, istotnego współcześnie mechanizmu kulturowego. Druga płaszczyzna analizy dotyczy odbioru sztuki interaktywnej. W artykule pokazano, że interaktywność sztuki niesie ze sobą znaczącą odmienność takiej sztuki w stosunku do sztuki proscenicznej, powodując intersujące zjawisko, wynikające z ingerencji odbiorcy w dzieło sztuki oraz po części integrację z dziełem. Dla zobrazowania interaktywnej partycypacji i sztuki, odwołam się do kilku współczesnych przykładów dzieł artystycznych, takich jak np. interaktywna instalacja wykorzystująca grafikę $3 \mathrm{~d}$ lub prace Post-Internet Art.

Słowa kluczowe: sztuka interaktywna, partycypacja, media elektroniczne, cyberkultura 